\title{
Prediking oor die Koninkryk van God: 'N Uitdaging in 'N NUWE KONTEKS VAN ARMOEDE
}

Author:

Hennie J.C. Pieterse ${ }^{1}$

\section{Affiliation: \\ ${ }^{1}$ Departement Praktiese \\ Teologie, Universiteit van \\ Pretoria, Suid-Afrika}

Correspondence to:

Hennie J.C. Pieterse

e-mail:

pietehjc@absamail.co.za

\section{Postal address:}

262 Marraisstraat,

Brooklyn 0181, Pretoria,

Suid-Afrika

\section{Keyword:}

godservaring;

voorseinigheid van God;

Heidelbergse kategismus; regstellende aksie; koningkryksgelykenisse

Dates:

Received: 09 July 2008

Accepted: 10 Feb. 2009

Published: 02 Mar. 2009

How to cite this article: Pieterse H.J.C., 2009,

'Prediking oor die koninkryk van God: 'n Uitdaging in 'n nuwe konteks van armoede', HTS Teologiese Studies/ Theological Studies 65(1), Art. \#106, 6 pages. DOI: 10.4102/hts.v65i1.106

\section{This article is available} at:

http://www.hts.org.za

\section{Nota:}

Hennie J.C. Pieterse is 'n Emeritus professor by die Universiteit van Suid-Afrika, asook 'n buitengewone professor by die Fakulteit van Teologie by die Universiteit van Pretoria.

(C) 2009. The Authors. Licensee: OpenJournals Publishing. This work is licensed under the Creative Commons Attribution License.

\section{ABSTRACT}

Preaching on the kingdom of God: A challenge in a new context of poverty The question addressed by this article has to do with the content of preaching in the context of laws about affirmative action affecting white South Africans. This question results from the findings of previous research by the author regarding the experience of God by people negatively affected by these laws. The article argues that preaching of the parables on the kingdom of God can help people to find hope and a meaningful existence as followers of Jesus. The contemporary understanding by New Testament scholars of how the parables should be interpreted is discussed. Most of the authentic versions of the parables of Jesus are diaphoric metaphors. The kingdom message of Jesus to the subculture of the disreputable poor creates an alternative life world in contrast to the violence, injustice and discrimination of worldly states. The eschatology of the parables in Matthew should be interpreted as ethical eschatology real in nature. Interpreting these parables ethically helps pastors to preach Jesus' kingdom message anew.

\section{INLEIDING}

Lidmate van die Afrikaanssprekende Reformatoriese kerke en die Afrikaners in die algemeen het tot en met die politieke omwenteling van 1994 ' $n$ halwe eeu van voorspoed en veiligheid geniet. Met die beleid van transformasie van die nuwe regering waarvolgens swart mense op groot skaal in poste geplaas moet word met die gevolg dat witmense oor die algemeen in die publieke dienste en die groot nywerhede vervang moes word, het die konteks van die wit Afrikaners drasties verander. Hierdie verandering tref ook diegene wat lidmate van die kerk is. Met die Wet op Gelyke Indiensneming (Wet 55 van 1998), die versterking van hierdie wet met die Wet op Breed-gebaseerde Swart Ekonomiese Bemagtiging (Wet 53 van 2003) en die Wet op Vaardigheidsontwikkeling (Wet 97 van 1998 en Wet 31 van 2003) word wit mans wat Suid-Afrikaanse burgers is, as die 'nie-aangewese groep' aangedui. Dit beteken dat hulle prakties ontneem word van werkgeleenthede, behalwe in private ondernemings, veral klein private ondernemings waarvan die jaarlikse omset nie meer as vyf miljoen rand is nie. Wit mans wat nie eintlik entrepreneurs is nie, is gedoem tot werkloosheid. In Suid-Afrika is daar nie sosiale voorsiening vir eerste werksoekers nie. Diegene wat gewerk het en ontslaan word, kry vir slegs nege maande 'n klein toelae uit die werkloosheidsversekeringsfonds. Talle mense wat jare by instansies in diens was, is in die laaste paar jaar deur die beleid van regstellende aksie uit diens gestel - sommige op jong leeftyd en met klein pakkette. Die konteks waarin ons prediking in die Afrikaanstalige kerke vir hierdie persone (waarvan talle jong mense is) plaasvind, het dus in die laaste jare verander. Armoede kruip in baie gesinne meedoënloos nader. Ek het in 2005-2006 ondersoek gedoen na die Godservaring van mense wat onder regstellende aksie gely het. Die belangrikste bevinding was dat die enigste hoedanigheid van God wat later in hulle situasie sin gemaak het, die voorsienigheid van God is (kyk 2 hieronder).

Die konteks waarin Sondag X van die Heidelbergse Kategismus oor die voorsienigheid van God geskryf is, het vreemd geword vir ons gemeenskap en vir die moderne Westerse mens. In uiters moeilike leefomstandighede was die belydenis in die Kategismus ook 'n dokument van troos vir die gelowiges van destyds (vgl H D A du Toit [1963] se redakteursinleiding). Toe die idees van die Reformasie in Frankryk uitgeslaan het, moes Calvyn vir sy lewe vlug vir die Rooms-Katolieke Kerk en koning Frans I. Hy was daarna, saam met sovele aanhangers van die gedagtegoed van die Reformasie, 'n vlugteling. Diegene wat nie kon wegkom nie, moes die prys vir hulle geloof op die brandstapel betaal (vgl Van't Spijker 1986:2731; Wendel 1963:47; Dankbaar 1982:17-22). Sedert 1544 was daar op verskillende plekke 'n groeiende stroom vlugtelinge. In Londen kom 'n gemeente van vlugtelinge tot stand. Dit het bestaan uit Frans- en Nederlandssprekende gemeentelede (Barnard 1981:354-362). Die Nederlandse gemeente vlug weer uit Londen en gaan na Denemarke, Rostock, Lübeck, Hamburg en 'n groep uiteindelik na Frankfurt, waarvan 'n deel weer na Frankenthal verhuis (Barnard 1981:362). Hierdie mense het alle aardse besittings verloor, was vervolg, ontwrig, arm en in 'n baie moeilike lewensituasie. In hierdie konteks moes die geloof in die voorsienigheid van God vir hulle 'n geloofservaring in hul persoonlike omstandighede gewees het, asook die grond vir hulle hoop op oorlewing. Dit blyk ook uit die hageprediking teen die jaar 1566 in die Nederlande. Reformatoriese gelowiges wat nie openlik hul godsdiens kon beoefen nie, het in die veld bymekaar gekom en die predikers het op waentjies of op gerfhope gestaan en preek. Daar was 'n honger na die Woord van God. Wie was die hoorders? ' ... het is een groep die er ongunstig uitziet ... vreemde werklui, die naar onze stad (Gent) toegekomen zijn om werk te vinden' (Runia 1985:19). Mense moes noodwendig wapens saamneem. 'Overal zie je wapenen, net als bij troepen te velde' (Runia 1985:21).

Die belydenis van die voorsienigheid van God in hierdie sin het ook nog tot in die negentiende eeu in Nederland (en ook in Suid-Afrika) in die persoonlike, materiële lewe van gelowiges sin gemaak. My vrou se oumagrootjie het in die tweede helfte van die negentiende eeu ná die dood van haar man in Amsterdam agtergebly met agt kinders waarvan twee reeds oorlede was en een nog gebore moes word. Haar seun Abram was die oudste en het aan 'n Christelijke Kweekschool voor Onderwijzers te Nijmegen gestudeer. Sy was brandarm en moes ' $n$ bestaan maak uit ' $n$ klein hoede- en pettewinkeltiie terwyl sy teen betaling ook mense se wasgoed gewas en gestryk het. Sy het gereeld briewe aan haar seun in Nijmegen geskryf. My vrou het via haar moeder die briewe geërf. Hier volg 'n uittreksel uit een van die briewe wat haar ervaring van God se voorsienigheid illustreer: 7 October 1888. 
... Lieve Abram, tob maar niet te veel over mij, de Heere zal wel voor mij en de kinderen zorgen. Hij zorgt ook in zo ruime mate voor $U$. Wij zien toch, lieve Bram, dat wij zonder hem niets kunnen en niets zijn; en wat heeft Hij ons in de laatse tijd niet vele bewijzen zijner goedertierenheid en trouw gegeven, U buiten, mij hier. O lieve kind, verwonderlijk zouden wij zeggen als wij niet wisten dat wij een rijke God in de Hemel hadden. Donderdag is het acht dagen geleden dat $i k$ niet wist wat ik je broertjes en zusjes zou te eten geven, ik had niets, ik zei: "jongens, Moe heeft niets," maar zie, nauwelijks heb $i k$ het hun gezegd, of daar komt voor 18 cents mangelgoed (vir die wasserijtiie). Ik moest om een boodschap en kom weerom, daar liggen twee broden op tafel, ik zeg: "O, dit is van de Heere!" 's Morgens moet je weten ( $i k$ wou aan niemand vertellen hoe benauwd het bij ons aan huis was), boog ik mijn knieën en zeide "och Heere! U weet wat Uw arm kind behoeft, gij zult ons geven wat wij nodig hebben," en ziedaar! Eer zij roepen, zegt de Heer, zal ik antwoorden. De volgende dag kwamen er weer twee en zaterdags vier broden van Simons, met de boodschap dat mij alle dagen twee broden zouden gestuurd worden tot wederopzeggens door een heer die het niet weten wilde. $\mathrm{Nu}$ lieve jongen, dat was uit de hand van hem die mildelijk geeft en niet verwijt. Mijn brood is dus zeker. Nu lieve jongen, wentel in alles uwen weg op den Heer, want Hij zorgt ook voor U en och lieve Abram geef uw gehele hart aan Hem, Hij is het zo waard.

Vir gelowiges in die konteks van ontworteling in die eeu van die Reformasie en die tye daarna het die formulering van die voorsienigheid van God soos 'n beskermende boog oor hul lewens gefunksioneer.

Kritiek oor die voorsienigheid van God soos dit in Sondag X van die Kategismus verwoord is, vind ons byvoorbeeld by Noordmans (1949). Uit my ondersoek oor die Godsbelewing by slagoffers van regstellende aksie het dit na vore gekom (in hulle verwoording op voetspoor van my konseptualisering) dat die voorsienigheid van God feitlik die enigste hoedanigheid van God is wat ná hulle ellendige ervaringe sin gemaak het (Pieterse 2008). Voortvloeiend uit hierdie ondersoek kom die vraag nou na vore:

Hoe preek ' $n$ mens in ons konteks van regstellende aksie sodat die boodskap sin maak vir ons lidmate? Welke Bybelse inhoud, welke boodskap van ons prediking sou relevant en sinvol wees in hierdie huidige situasie?

Dit is die vraag wat in hierdie artikel ondersoek word.

Om hierdie vraag te antwoord, sal ek eers die resultate van my ondersoek by die slagoffers van regstellende aksie en hul Godsbelewing in hierdie situasie opsommend stel. Daarna sal ek die verstaan van Jesus se koninkryksgelykenisse oor ons sorge aan die orde stel. Ten slotte sal die eietydse verstaan van die koninkryksgelykenisse vir die prediking in ons konteks aanbeveel word.

\section{RESULTATE VAN 'N ONDERSOEK BY SLAGOFFERS VAN REGSTELLENDE AKSIE OOR HUL GODSERVARING}

In 2005-2006 het ek 'n ondersoek gedoen onder die slagoffers van regstellende aksie om vas te stel wat hul Godsbelewing in hierdie omstandighede is waar hulle (volgens hulle oordeel en gevoel) onregverdig behandel is in die verlies van hul werk, of waar hulle verhoed word om by instellings te werk (kyk Pieterse 2008). In die prakties-teologiese ondersoek oor hierdie saak het ek gewerk met die metode van teologiese 'konseptualisering van die relevante teologiese teorie oor die handeling' wat ter sprake is (1), gevolg deur' $n$ ' $k w$ alitatiewe ondersoek na die praktyk' (2), wat uitloop op ' $n$ 'interaksie tussen teorie en praktyk as ' $n$ hermeneutiese proses' (3). Hierdie wetenskaplike stappe behoort ' $n$ mens dan te help om nuwe insigte te kry vir die ontwerp van 'n 'meer praktykgerigte 'teorie (vgl Pieterse 1993:169-190; Heitink 1993; Immink \& Pleizier 2005; Van der Ven, Dreyer \& Pieterse 2004).

In hierdie ondersoek het ek eers die hoedanighede van God (hoe God teenoor ons is) gekonseptualiseer vanuit die perspektief van 'n prediker in die volgende teologiese konsepte: God se liefde, almag, goedheid, voorsienigheid en onveranderlikheid (vgl Pieterse 2008; Heyns 1978; Baars 2004; Berkhof 1973; Berkouwer 1950; Durand 1976; Jonker 1989; Van Niftrik 1953). Om die effek van die trauma van hierdie soort werkverlies te verstaan, het ek ook die sosiologiese teorie van Seeman (1959) gebruik. Volgens hierdie teorie vind daar in so 'n situasie ' $n$ vervreemding of aliënasie plaas wat uit 'vyf dimensies bestaan, naamlik magteloosheid, betekenisloosheid, normloosheid, isolasie en self-aliënasie' (selfvervreemding) (Seeman 1959:783791). Vir 'n volledige bespreking van die hoedanighede van God en die teorie van Seeman kyk Pieterse (2008).

Die tweede aspek van die ondersoek is deur middel 'van onderhoude in ' $n$ kwalitatiewe ondersoek met ' $n$ steekproef van slagoffers van regstellende aksie' uitgevoer waarin die halfgestruktureerde onderhoudskedule die konsepte oor die hoedanighede van God en die aliënasiebegrip reflekteer. 'n Teikenpopulasie is geïdentifiseer met die oog op 'n oordeelkundige steekproeftrekking (vgl Polit \& Hungler 1989:172), naamlik NG Kerk gemeentes in Pretoria met lidmate wat slagoffers van regstellende aksie is. Drie gemeentes wat verteenwoordigend is van ' $\mathrm{n}$ hoër middelklas omgewing (gemeente A), ' $n$ middelklas omgewing (gemeente B) en 'n laer middelklas omgewing (gemeente C) is genader om my in kontak te bring met mense wat in so 'n situasie verkeer. Ná 'n proeflopie met ' $n$ groter groep is vyf respondente binne die raamwerk van oordeelkundige steekproeftrekking gekies. Hierdie respondente kom uit die drie gemeentes en is slagoffers van die verskillende strategieë van die nuwe bestuurders wat regstellende aksie bedryf. Die respondente bestaan uit twee werksoekers wat pas hul opleiding voltooi het - een met matriek en een met ' $n$ opleiding as mediese dokter ('n vrou), albei uit gemeente C; en drie mense wat in loopbane gestaan het - een uit gemeente A en twee uit gemeente B. Laasgenoemde drie respondente is jonger as vyftig jaar oud. $\mathrm{Al}$ die respondente is wit, Afrikaanssprekend en lidmate van die NG Kerk. Die onderhoude het twee keer per respondent, telkens met verloop van ' $n$ hele aantal maande, plaasgevind.

Die resultaat van die ondersoek toon dat vanweë die vervreemdingsprosesse volgens die teorie van Seeman (1959) die hoedanighede van God se liefde, goedheid, almag en onveranderlikheid in die donker dae nie eintlik in hul lewens sin gemaak het nie. Hulle kon in hul gebede haas geen kontak met God maak nie. Nadat hulle deur middel van vriende en familie weer ' $n$ werkie in ' $n$ klein private onderneming sonder voordele gekry het, was die enigste hoedanigheid van God wat'n geleefde geloofservaring was, die voorsienigheid van God. Hulle het in die laaste onderhoude op verskillende maniere hierdie ervaring verwoord: God het weer vir hulle voorsien.

\section{DIE KONINKRYKSBOODSKAP VAN JESUS}

My verkenning van die teologie met die oog op die siening oor God se voorsienigheid geskied uiteraard vanuit die perspektief van 'n prediker met die oog op die prediking. In die lig van my bevinding by die respondente oor die uitsprake dat God weer vir hulle voorsien het, was ek genoodsaak om 'n teologiese verkenning van Sondag $X$ van die Heidelberse Kategismus se formulering te doen, met die vraag in my agterkop: Wat moet die boodskap van ons prediking in hierdie soort konteks wees? Moet ons Sondag X preek? In die proses het die insigte van Noordmans en die meer genuanseerde denke oor die koninkryk van God my soeke in 'n ander rigting gestuur.

Noordmans argumenteer dat die werke van die Vader nie volledig deur die Kategismus in die Sondae II-IV beskryf is nie. Nie alleen die wet nie, maar ook die evangelie kom die Vader toe. Die 'wet' is immers die geringste van die werke van die Vader. Die 'evangelie' van die 'koninkryk' is 'n baie groter deel van sy werke. Ons moet oor die koninkryk praat as dit oor die Vader gaan (Noordmans 1949:50). Die koppeling van die koninkryk en 
God as Vader is 'n wins by Noordmans. Eietydse navorsing het egter hierdie koppeling ryklik verdiep. Van Aarde (2001:42-44) toon dit duidelik aan:

Jesus ... the peasant who came from the Galilean village of Nazareth ... [a]fter he left the circle of the Baptist ... [began his life] ... by an absolute trust in God as his Father, while the insignificant, the nobodies of the Galilean society, formed his audience when he spoke about his "Father's rule" ... His stories were symbolic in nature, open-ended, and shocking. His acts, particularly those of healing, were of the same nature and can be considered as metaphors in themselves pointing to the idea of resocializing ... He envisaged the kingdom of God neither as primarily cataclysmic in nature... nor as comparable to earthly kingdoms where humaneness vanishes behind various symbols of power and hierarchy. Instead, he saw it as comparable to a household in which distorted relationships are healed by means of the "ethos of compassion" and God's unmediated presence ... From this picture, Jesus' use of the metaphor of the Kingdom of God is remarkable... Jesus experienced God's presence in the midst of and despite depressing circumstances. His symbolic conception of God was often expressed, though not exclusively, in terms of familial relationships between a father and son ... Jesus was a social outcast and not a kind of Robin Hood figure born within an imperial kingdom who only docetically fulfilled the role of being poor in his act of being the hero of the helpless in society.

Die verhouding tussen wet en evangelie by Noordmans vertoon egter'n dualisme. 'n Mens sou eerder met dialektiek tussen wet en evangelie moet werk. Buitendag toon aan dat as 'n mens met die simboliese universum (dinge van God) en 'n sosiale universum (dinge van die wêreld) werk, vorm die hermeneutiese proses 'n dialektiek (Buitendag 2006:347). Hy verwys na Peter Berger (met Luckmann as mede-outeur) waarin hulle die kritiese prioriteit van die simboliese universum bo die sosiale universum in hierdie dialektiek aantoon (Buitendag 2006:348). 'n Simboliese universum, volgens Berger en Luckmann (1967:96) is waar:

all the sectors of the institutional order are integrated in an allembracing frame of reference, which now constitutes a universe in the literal sense of the word, because all human experience can now be conceived of as taking place within it. The symbolic universe conceived of as a matrix of all socially objectivated and subjectively real meanings, the entire historic society and the entire biography of the individual are seen as events taking place within this universe.

(Buitendag 2006:348)

In die verdere nuanseringvan die siening van wet en evangelie aangeraak deur Noordmans, is die opmerking van Dorrien oor Berger se begrip van die 'sacred canopy' (Berger 1967) belangrik.

If order was the first need of all, the crucial function of religion was its ordering or "nomizing" capacity. The socially constructed world was most importantly an "ordering of experience" in which a meaningful order (or nomos) was imposed upon the experiences and meanings of human subjects. From a sociological standpoint, Berger reflected, the purpose of religion is to construct a sacred cosmos. Religion offers a protective canopy of transcendent legitimacy, meaning, and the precarious constructions that society calls 'reality'. The fate of any social order is therefore inevitably bound up with the fate of religion.

(Dorrien 2001:32; kyk Buitendag 2006:348)

Noordmans argumenteer verder in sy nadenke oor die voorsienigheid van God in die belydenisskrifte dat die liggaamlike ellende van mense nogal onderbeklemtoon is. In die konteks van die 'sielenood' waaruit die Reformasie gebore is, is daar nie genoeg aandag gegee aan die uitwendige ellende wat in die gesigsveld van die evangelie is nie, naamlik die blindes, kreupeles, geraaktes deur onreg, dowes, armes. En dan nie vanuit die gesigspunt van die algemene voorsienigheid wat die heidene ook bely nie, maar in verband met die naby-wees van die koninkryk van die hemele. In die lig van die koninkryk kom die 'geregtigheid' van God ook by hierdie soort ellende in beeld (Noordmans 1949:50). In Jesus se prediking spoor hy ons aan om ons nie te bekommer oor wat ons sal eet of drink of aantrek nie, maar om ons te beywer vir die koninkryk van God - 'n koninkryk waarin vrede, liefde en geregtigheid heers (Matt 6:25-34;5:1-12;22:34-40). Dit gaan om die sorge oor vrede, barmhartigheid, vergewensgesindheid, reinheid, waarheid, lydsaamheid, mededeelsaamheid en die liefde tot die vyande. Dit is die soort geregtigheid wat Jesus se dissipels moet soek volgens die evangelie van Matteus (Noordmans 1949:52). Die formulering oor die voorsienigheid in Sondag $\mathrm{X}$ is georiënteer aan natuurlike teologie (Noordmans 1949:67). Ten opsigte van Noordmans se kritiek op die natuurlike teologie wat in Sondag $\mathrm{X}$ van die Heidelberse Kategismus funksioneer, moet verder genuanseer word. Buitendag onderskei tussen natuurlike teologie en 'n teologie van die natuur (Buitendag 2006a:793). Natuurlike teologie is tereg nie in die reformatoriese teologie aanvaarbaar nie. Noordmans toon egter aan dat die Nederlandse Geloofsbelydenis (NGB, artikel 13) meer aanvaarbaar oor die voorsienigheid van God praat (Noordmans 1949: 58-59). 'n Teologie van die natuur wat beter in die NGB (artikel 13) funksioneer, is 'n legitieme teologie. Hierdie saak het ons ook al in die praktiese teologie ondersoek (Van der Ven, Dreyer \& Pieterse 2000)

Met die kritiese omgang van Noordmans se uitspraak oor Sondag $X$ en die beter verstaan van die koppeling van die koninkryk en God as Vader in Jesus se boodskap, het my soeke na die inhoud van die prediking vir mense in materiële nood in ons tyd in die rigting van die koninkryksboodskap van Jesus gedraai. Dit sluit ook aan by die bydrae van Gerrit de Kruijf (Armoede en ethiek) in die bundel geredigeer deur Immink en Vos (2008).

\section{Hoe moet die prediker-eksegeet Jesus se gelykenisse oor die koninkryk van God lees?}

In die paragrawe wat volg, sal ek slegs 'n lyn trek van die ontwikkeling in die Nuwe Testamentiese wetenskap oor die verstaan van hierdie gelykenisse. Dit lê nie op die weg van 'n homileet om hierdie diskussie grondig volledig te kan bespreek nie. Daar het 'n wending gekom in die verstaan van Jesus se gelykenisse oor die koninkryk van God toe dit nie meer as ontologiese konsepte verstaan is nie. Hiermee word bedoel dat die taal waarmee die 'konsep "koninkryk"' aangedui word nie 'n 'ontiese' aangeleentheid is nie. Die uitdrukking 'koninkryk van God' is dus nie 'wesenlik' dieselfde as iets soos 'n streek (regio) of 'n plek of een of ander buite-wêreldse ruimte nie. Dit verteenwoordig eerder taal wat 'analogies' (nie 'ontologies') verwys na 'n besonder praktiese saak. Praxis word dus simbolies verwoord.

Praktiese teoloë het van hierdie verandering kennis geneem in die werk van Van der Ven in sy ontwikkeling van die empiriese aspek in die beoefening van die praktiese teologie (Van der Ven 1993). Die praktiese teologie was ná die Tweede Wêreloorlog in Europa in 'n krisis. Die metode om die vak te benader as toepassing van die dogmatiek het nie meer aan pastors die taal verskaf om die evangelie in die krisis te bring nie (Heyns \& Pieterse 1990:97; kyk Heitink 1993:14-16).

Die wending in die ontwikkeling van 'n eie wetenskapsteoretiese begronding en ' $n$ eie vakbenadering het begin met H-D Bastian (1968) se opspraakwekkende artikel. Nie meer is die dogmatiek ons basis nie, maar 'n studie van die woorde wat ons gebruik. Die kommunikasie in ons pastorale handelinge moet empiries bestudeer word. Op grond van hierdie wending is die kommunikasie van die evangelie in die bedieningspraktyk beskou as handelinge, 'kommunikatiewe handelinge' in diens van die evangelie (Pieterse 1993). Die vak werk nou met 'n kritiese bi-polêre spanning tussen teorie en praktyk (Heyns \& Pieterse 1990:26-35). Die gangbare teologiese teorieë vir 'n besondere handeling word gekonseptualiseer in 'n konseptuele raamwerk, die praktyk wat deur hierdie teorie gerig word, word empiries ondersoek en die (bestaande) teorie en die empiriese bevindinge in 'n kritiese interaksie gebring. Hieruit kan dan 'n 
verstelde praktykteorie ontwikkel word vir die kontemporêre konteks (Zerfass 1974:167). Vanuit hierdie insigte het die huidige hermeneuties-kommunikatiewe benadering ontwikkel. Binne hierdie benadering het die 'vraag na die normatiewe oriëntasie van die vak' ontstaan, gesien die feit dat ons die normatiewe grondslag van die sistematiese teologie verlaat het. Daar was konsensus binne hierdie kring van wetenskappers dat dit die 'koninkryk van God' moet wees (kyk Pieterse 1986:2). Niemand het dit egter nog sistematies uitgespel nie.

Johannes van der Ven (1993) het hierdie taak aangepak. Binne die hele universum van die sake wat in die praktiese teologie met 'n empiries-kontekstuele inslag ter sprake kom, het hy in hoofstuk 6 van sy boek die vraag van die normatiwiteit in die vak aangepak. In sy bespreking van die normatiewe refleksie op die praxis wat die praktiese teologie as ' $n$ hermeneuties-kommunikatiewe praxis bestudeer, werk hy met die basileia-simbool in Jesus se praxis as die normatiewe raamwerk vir 'n ekumeniese praktiese teologie. Daaronder behandel hy die eskatologiese perspektiewe in hierdie normatiewe refleksie. In sy aanvanklike teks wat hy aan kritiese lesers voorgelê het, het hy nog van 'n konseptuele benadering tot die koninkryk van God uitgegaan.

Sterk kritiek van die kant van sy Nuwe-Testamentiese kollegas het daartoe gelei dat hy onder hulle aanwysing Norman Perrin (1976) gaan lees het. Hy sluit aan by Perrin en formuleer dan soos volg oor die verstaan van Jesus se gelykenisse: 'These texts contain no concepts that could serve as building blocks for an argumentative analysis' (Van der Ven 1993:69). Dit moet as 'simbole,' gegroepeer word, sodat die simbool van God se koninkryk verstaan kan word (Van der Ven 1993:73-76).

Publikasies van nuwe-testamentici beskryf die verstaan van Jesus se gelykenisse as simbole in groter detail (vgl bv Scott 1990). Perrin (1976:29-33) sluit by Peter Wheelwright aan en onderskei twee tipes simbole, naamlik "tensive" and "steno" symbols ... A steno symbol has a one-to-one relationship with what it represents. A tensive symbol represents a set of meanings, which cannot be exhausted nor adequately expressed by any one referent' (Reinstorf \& Van Aarde 1998:608). In Jesus se gelykenisse is 'koninkryk' duidelik ' $\mathrm{n}$ 'tensive' simbool. Die ontwikkeling in die rigting van die verstaan van Jesus se gelykenisse as metafore het gedaag met die insig dat metafore nie net uit enkele woorde bestaan nie, maar dat dit ook kort narratiewe kan wees. Van Aarde (1994:236-240) argumenteer oortuigend dat alle gelykenisse van Jesus as metaforiese narratiewe gesien moet word. Scott se beskrywing van die verhouding tussen narratief en simbool is belangrik om gelykenisse te verstaan:

But just understanding the narrative is not sufficient, for it is laid beside or is handled for the symbol of the kingdom of God. It is in laying a narrative beside a symbol that parable occurs, for symbol is implicated in the parable's discourse. The kingdom makes narrative religious; the narrative discloses the kingdom; together they create parable.

(Scott 1990:62)

Gelykenisse is kunswerke soos gedigte. Dit dra nie net sekere waarhede nie, maar veral voorstellings van die werklikheid, wat die essensie van metafore is. ' $n$ Egte metafoor is meer as ' $n$ teken - dit is 'n draer van die realiteit waarna dit verwys en daarom betrek dit die hoorder as 'n aktiewe deelnemer in die wêreld wat dit skep.

Parable as metaphor demands that the parable is never done away with. The parable remains open-ended and polyvalent, with the readers always involved in a participatory role. They are drawn into the world of the parable through which they then view their own world.

(Reinstorf \& Van Aarde 1998:609)

Die gelykenisse behoort ook as diaforiese metafore gelees te word. Scott onderskei tussen epiforiese en diaforiese metafore:

When the symbol is encompassed in a discourse, the discourse can either exploit these notions (epiphor) or turn against the associations (diaphor). Most common metaphors are epiphoric: the associations are bearers of the implied symbolic meaning. But in the Jesus tradition, the relation is frequently diaphoric: Jesus' discourse changes or challenges the implied structural network of associations.

(Scott 1990:61)

Thomas Wright (1992) se siening van kritiese realisme het 'n 'epistemologie' wat by bogaande verstaan van die gelykenisse pas, op die tafel geplaas. Kritiese realiste beskou literatuur as die verhale wat wêreldbeskouinge artikuleer. Hierdie narratiewe het die potensiaal om verskillend van die leser se wêreldbeskouing te wees. As dit eenmaal geskryf is, het dit ook die potensiaal om onafhanklik van die outeur te bestaan. By die lees van literatuur word die leser betrek in 'n gesprek met die teks.

His reading seeks to be true to itself, and to the public world, while always open to the possibility of challenge, modification, and subversion.

(Reinstorf \& Van Aarde 1998:612)

Om hierdie openheid tot die teks te kan verkry, sal die predikereksegeet sigself moet oopstel vir 'n hermeneutiek van suspisie (kyk Vos 2008). Hierdie suspisie, op voetspoor van Ricoeur, moet op die self gerig word en op die sisteem soos die geloofsgemeenskap of kultuur waarvan die leser deel is. Die leser se ideologie en vooroordele moet onder die soeklig van byvoorbeeld feministiese en ideologie-kritiek geplaas word. Ricoeur se opvatting oor die hermeneutiek van suspisie stel die predikereksegeet in staat om die teks meer onbevange self aan die woord te laat kom. Predikers neig dikwels daartoe om die teks met 'n eerste naïwiteit te lees. Eers as die leser aan hierdie selfondersoek blootgestel was, kan na 'n tweede vorm van verstaan beweeg word wat hermeneutiek van herwinning/rekolleksie/geloof genoem word en so kan 'n tweede naïwiteit bereik word (Vos 2008:114-119). Hierdie verstaansproses binne 'n raamwerk van kritiese realisme geskied deur 'n voortdurende dialoog tussen die wêreld van die leser en die wêreld van die teks (Reinstorf \& Van Aarde 1998:611). Om die gelykenisse as diaforiese metafore te kan ondersoek, word die ondersoek gedoen met die narratiewe struktuur van die gelykenis as vertelling as uitgangspunt. Hierdie narratiewe ondersoekmetode word met groot sukses in ons eie kring uitgevoer (kyk Van Aarde 2007a:225-323; vgl 2008a:529-565; Van Eck 2008:567-597).

Om die gelykenisse reg te verstaan, moet die leser nie die eietydse konteks in die konteks waarin die gelykenisse opgeskryf is inlees nie. Die leefwêreld en die lewensbeskouing van die eerste-eeuse Oos-Mediterreense mens wat die konteks van die geskrifte van die Nuwe Testament bepaal, verskil grootliks van ons Westerse eietydse verstaan van die wêreld (vgl Malina 1993). In 'n ander verband wys ook Schottroff daarop dat antropologiese dualisme, gebaseer op die Westerse filosofiese tradisies, Bybelse interpretasie beïnvloed het, byvoorbeeld by die eksegese van 1 Kor 15:44 (Schottroff 2006:83). Ten opsigte van die verstaan van eskatologie in Markus toon Van Eck (2008:570) aan dat die tradisionele verstaan van tyd by die konsep van eskatologie 'n moderne konstruk is, gebou op ons Westerse idee van tyd. Vir die verstaan van die konteks van die Nuwe-Testamentiese wêreld met die oog op armoede daar en armoede in ons konteks is dit ook van die uiterste belang om die sosiale konteks van die tyd van Jesus goed te begryp (Van Aarde 1988:837-843; vgl Malina 1987: 354-367). Eers dan kan ons 'n redelik goeie interpretasie probeer maak van wat die gelykenisse vir ons sê in ons prediking vandag.

Wanneer ons die koninkryksgelykenisse op hierdie manier lees met die oog op die prediking daarvan in die konteks van groeiende armoede by lidmate van die Afrikaanssprekende Reformatoriese kerke, word nuwe insigte vir die predikereksegeet oopgemaak.

\section{Armoede in die leefwêreld van die Nuwe Testament}

Ons moet onderskei tussen die omstandighede tydens die optrede van Jesus en die omstandighede wat geheers het in die tyd van 
die Nuwe Testamentiese skrywers, omdat die evangelies in die vroeg-kerklike omstandighede geskryf is (Van Aarde 1988:831). Die tyd ná die vernietiging van die tempel in Jerusalem (70 nC) is die konteks waarin Matteus geskryf is. Volgens Van Aarde (2008b:178-179) het dit ontstaan in die gebied van die noordelike Galilea en die suidelike Sirië waar groepe Jode hulle in dorpies gevestig het. Onder hulle was daar volgelinge van Jesus wat die ekklesia genoem is en die Jode wat Jesus verwerp het en steeds die Messias verwag het.

Amid Roman exploitation, scribes were engaged in village restoration. Conflict existed between two sets of scribes: the Jesus followers, who acknowledged him as messiah and the other Israelites who upheld the traditional view of the messiah.

(Van Aarde 2007b:423; vgl ook Van Aarde 2008b:179; Van Eck 2008:592 in verband met die Markaanse gemeente)

Die skrywers van die Nuwe Testament se geskrifte was beter af as diegene aan wie Jesus die koninkryk van God gepreek het. Die omstandighede waarin Jesus en sy volgelinge geleef het, was neerdrukkend van aard (Van Aarde 1988:832).

Die sosiale kategorieë in Jesus se tyd het bestaan uit 'aristokrate' (ongeveer 5\% van die bevolking) en 'die volk van die land' (ongeveer 95\%) (Van Aarde 1988:840). Die boonste laag het uit die leiers en die regerende klas bestaan. Dit het diegene wat uit adellike families gebore is en aangestelde burokrate ingesluit. Politieke mag het rykdom voorafgegaan. Priesterhoofde, erkende familiehoofde (die oudstes) en belangrike amptenare het hieronder geval. Status en nie, soos in ons tyd, rykdom nie het die belangrikste rol gespeel om 'n posisie in die klasse te verkry. Die res het bestaan uit die kleinboerderygemeenskap, die ambagslui en diegene wat 'onrein' werk gedoen het soos leerlooiery. Onder die 95\% van die 'volk van die land' onderskei ons respektabele armes en by die heel onderste klas die onrespektabele armes. Hulle is feitlik geen plek in die samelewing gegun nie - dit is mense wat hul grond verloor het, dagloners en diegene wat nie 'n beroep kon beoefen nie (Van Aarde 1996:959-960). Die term 'onrespektabele armes' kom van T R Sarbin (1970: 29-46) wat na aanleiding van studies in ons tyd onderskei tussen 'respektabele armoede' (diegene wat hoofsaaklik om ekonomiese redes arm is) en 'onrespektabele armoede' wat meer as net ekonomies is en wat 'n subkultuur vorm. Dit is gemarginaliseerde mense. Van Aarde (1996:953) vind hierdie begrippe bruikbaar om ons te help om 'n sig op die relevante gedeeltes in die Nuwe Testament te kry. Die sosiaalveragtes kan dan beskou word as die onrespektabele armes, wat eintlik veronderstel is om 'nikswerd' (nonpersons) te wees (Van Aarde 1996:955). 'Wanneer ons die "sosiaal-uitgestotenes", ofte wel die "onrespektabeles", wel as die "armes" definieer, doen ons dit in die sin van iemand wat binne die sosiale konteks van die leefwêreld van die Nuwe Testament nie in staat was om sonder barmhartigheidsondersteuning voort te bestaan nie' (Van Aarde 1996:961; kyk ook Van Aarde 1988:892-846).

Van Aarde onderskei dan agtien tipes 'ongelukkige' mense wat deur natuurlike oorsake of sosiale omstandighede as sosiaalveragtes in terme van 'onrespektabele' armes beskou is met wie Jesus volgens die Sinoptiese Evangelies bemoeienis gehad het (Van Aarde 1996:962)

Die meeste was siek mense of gestremdes, te wete blindes (Luk 4:18; Matt 11:5; Luk 14:13, 21), verlamdes (Matt 11:5; Luk 14:13, 21), melaatses (Matt 11:5; Luk 16:19-31), dowes (Matt 11:5) en siekes in die algemeen (Matt 25:31-46). Hierdie groep vorm ses van die gemelde agtien tipe "onrespektabele arm mense". Dertien vorm ' $n$ kategorie wat verband hou met ontworteling met betrekking tot familie-aangeleenthede, te wete die treurendes (Matt 5:3vv), hongeriges (Matt 5:3vv; 25:31-46; Luk 16:19-31), dorstiges (Matt 5:3vv; 25:31-46), melaatses (Matt 11:5; Luk 16:19-31), dowes (Matt 11:5), dooies (Matt 11:5), verlamdes (Luk 14:13,21), weduwees (Mark 12:42-43), huisloses (Luk 16:19-31), bedelaars (Luk 16:19-31; Matt 25:31-46), vreemdelinge (Matt 25:31-46), naaktes (Matt 25:31-46) en siekes in die algemeen (Matt 25:31-46). Vyf vorm 'n kategorie wat met ekonomiese probleme te doen het, te wete die hongeriges, dorstiges, huisloses, bedelaars en dié sonder klere. Slegs vier groepe van die 'onrespektabele arm mense' kan volgens Hollenbach (1987:55) op een of ander manier met politieke mag(mis)bruik in verband gebring word, te wete die gevangenes (Luk 4:18; Matt 25:31-46), onderdruktes (Luk 4:18), sagmoediges (Matt 5:3vv) en die melaatses. Vir hierdie "onrespektabeles", diegene onder die aristokrasie én onder die kleinboere, Jode én nieJode, het Jesus getoon en geleer hoe om te midde van neerdrukkende omstandighede op God se teenwoordigheid staat te maak. Hierdie teenwoordigheid is beleef in terme van die geloofsgemeenskap as 'n "denkbeeldige familie"

(Van Aarde 1988:844-845)

Ons sal hierdie groep sosiaal-veragtes vandag as die politieke en ekonomiese verontregtes beskou. Jesus was lid van die sosiaalveragtes as groep. Jesus het met 'n onwrikbare Godsvertroue die boodskap van die evangelie gebring en hierdie mense in die neerdrukkende omstandighede en die skynbare afwesigheid van God tot 'n bestaan van vertroue in die teenwoordigheid van God gelei (Van Aarde 1988:830).

Crossan het die vroegste dokumente ondersoek om vas te stel wat ná die dood van Jesus gebeur het. Hieronder tel "The Common Sayings Tradition", Q en die vergelyking met Thomas, asook Matteus en Lukas (Crossan 1998). Hieruit kan ons 'n beeld van Jesus se koninkryksboodskap rekonstrueer. Jesus het die aardse ryk met sy geweld en onreg ondermyn deur 'n etiese eskatologie in sy boodskap oor die koninkryk van God daar te stel.

Ethical eschatology is directed at the world's normal situation of discrimination and violence, exploitation and oppression, injustice and unrighteousness. It looks at the systemic or structural evil that surrounds and envelops us all and, in the name of God, refuses to cooperate or participate any longer in the process ... God is waiting for us to act ... God is not a violent God ... And the courage for it derives from union with transcendental nonviolence.

(Crossan 1998:284)

Volgelinge van Jesus vorm 'n alternatiewe gemeenskap as behorende tot die koninkryk van God teenoor die koninkryke van geweld en onderdrukking, en handel op ' $n$ n eie, niegewelddadige wyse in die naam van God eties daarteenoor op. Van Aarde (2008a:538) toon aan dat Jesus se begrip 'koninkryk van God' of in Matteus se terme die 'koninkryk van die hemel', ingebed was in die konteks van die etiese eskatologie (Van Aarde 2008a:541). Hy verwys na Malina (2001:35) wat praat van Jesus se 'social gospel'. Diegene wat sy boodskap hoor en ervaar moet hom volg in sy houding en dade. Jesus se koninkryksboodskap (en die verstaan daarvan deur Paulus) het 'n alternatiewe ruimte van menslike lewe en etiese optrede in God se teenwoordigheid geskep as kontras teenoor die Romeinse ryk met sy geweld, magsmisbruik en die ontmensliking van mense (Kwok Pui-lan, Compier \& Rieger [2007:47-61; kyk ook Carter 2006). Ons sou die waardes van God se koninkryk ook vandag kan profileer teenoor die staatsoptredes van ons tyd.

In Weren se ondersoek bevind hy dat die eskatologie in Matteus funksioneer as "n kontinue teenwoordige perspektief' deur middel waarvan die lesers opgeroep word om nie vrede te maak met die onmiddellike konkrete omstandighede nie, maar om dit eerder deur dade te oorwin. 'Het eschaton functioneert dus als een voortdurend aanwezig perspectief, dat uitdaagt om niet te berusten in de nood van dit ogenblik maar om concrete activiteiten te ontplooien waardoor die nood overwonnen wordt' (Weren 1979:190). Van Aarde (2008a:540) stel dit so: "n Eskatologiese uitspraak is daarom soos 'n etiese versoek'.

Van Eck kom in sy ondersoek na eskatologie en koninkryk in die Markus evangelie tot die konklusie dat koninkryk en eskatologie as uitruilbare terme beskou kan word. Volgens die Markusverteller is die eskatologiese gebeure 'die koninkryk' (Van Eck 2008:568, 689-583). Die narratiewe van Jesus se gelykenisse as metafore funksioneer op 'n wyse waar die koninkryk op elke tydstip wat dit gelees, ervaar en geglo word, 
teenwoordig is. Oor die begrip 'tyd' in die eskatologie van Matteus het Van Aarde grondig geskryf (Van Aarde 2008a:529565). Matteus se narratief verhaal hoe God vanuit die koninkryk van die hemel by Israel betrokke is. Nie in die tempel nie, maar op 'n ander manier, naamlik dat God self 'God-met-ons' geword het in Jesus, die Messias. Die gemarginaliseerdes wat van God se teenwoordgheid uitgesluit is, word nou ingesluit in die geloofsgemeenskap van die volgelinge van Jesus (Van Aarde 2008a:548). Wat die tyd betref van die gebeure voor-Pase, die 'opeenvolging' van die gebeure na-Pase tot by die paroesie en die 'opeenvolging' wat met die paroesie begin, is al drie die sekwensies nou in Matteus se plotintrige geïntegreer (Van Aarde 2008a:549). Matteus verwys (in teenstelling met die ander Sinoptiese Evangelies) na die derde 'opeenvolging' veral in die gelykenisse, maar in die narratiewe struktuur word in die plot van Matteus alleen die twee basiese tydsvlakke verteenwoordig (Van Aarde 2008a:550). Hierdie interpretasie is moontlik indien ' $n$ mens die tydsperspektief van die eerste-eeuse OosMediterreense mense ernstig neem. Hy vind die sleutel tot Matteus se tydsbegrip in die konsep van die draai van die gety waarin ervaarde tyd en verbeelde tyd in verband gebring word (Van Aarde 2008a:552-553). Matteus se siening is dat die einde reeds begin het ná die koms van die Seun van die mens en ná die opdrag aan en sending van die ekklesia. Die verteller skep 'n kontinuïteit en analogie tussen die voor-Pase sending van Jesus en die na-Pase sending van die dissipels. 'Die kontinuïteit en analogie bestaan daaruit dat Jesus as "God-met-ons" op albei hierdie tydsvlakke - voor- en na-Pase - teenwoordig gemaak word' (Van Aarde 2008:557).

Hierdie interpretasie is moontlik deurdat die historiese konteks van Matteus in ag geneem word, naamlik ná die vernietiging van die tempel in $70 \mathrm{nC}$. Matteus kyk terug en beskryf (met sy eie redaksionele hantering van die stof) die gebeure van die kruisiging van Israel se Messias sowel as sy visie op die koms van die Seun van die mens in hierdie terugskoue. Dit lyk of sy bedoeling hiermee was dat die kerk, wat swaarkry onder verdrukking en besig is met sy opdrag van sending aan alle mense, sal ervaar dat Jesus 'God-met-ons' is, want die volgelinge van Jesus het die koms van die Seun van die mens gesien (Van Aarde 2008a:559). Van Eck (2008:567-597) kom in sy ondersoek van eskatologie en koninkryk in die Evangelie van Markus - en denkende vanuit min of meer dieselfde vertrekpunte as Van Aarde (2008a:529-565) - tot ongeveer dieselfde konklusie oor die 'tyd' van eskatologie en koninkryk. In die taal van die homileet vandag: die koninkryk is 'nou' teenwoordig wanneer ons die koninkryksgelykenisse preek as narratiewe wat diaforiese metafore

\section{BEVINDINGS}

In die vorige fase van my navorsingsprojek is die Godservaring ondersoek van mense wat deur regstellende aksie, volgens hul siening op 'n onregverdige wyse, uit hul poste weggestuur is, of nie as jongmense werk kon kry nie (kyk Pieterse 2008). Die vraag wat in hierdie artikel hanteer is, het gegaan oor die 'wat' van die prediking in die konteks van regstellende aksie onder witmense in Suid-Afrika. Welke Bybelse 'inhoud', welke boodskap moet die prediking in hierdie konteks bring wat sin en hoop kan bring? Die verstaan van die koninkryksgelykenisse van Jesus is aan die hand van eietydse Nuwe Testamentiese ondersoek slegs in hooflyne bespreek. Die prediker-eksegeet behoort die gelykenisse as diaforiese metafore te lees waarin dit in die leefwêreld van die eerste-eeuse Oos-Mediterreense tydsverstaan geskryf is. Die koninkryk van God as 'n lewe in die teenwoordigheid van God is deur Jesus verkondig as reeds begin en as ' $n$ ander leefruimte teenoor die gewelddadige ryke van die wêreld waar ongeregtigheid heers. Die etiese eskatologie van die koninkryk beweeg die volgelinge van Jesus tot die uitleef van die geregtigheid, vrede en liefde binne hulle geloofsgemeenskappe.

Mense wat in ons eie konteks gemarginaliseer word, behoort in die geloofsgemeenskap van die Christelike kerk opgevang en sin en hoop gegee te word vir 'n lewe van vertroue in die teenwoordigheid van God waar sy koninkryk aangebreek het. Die prediking van die koninkryksgelykenisse van Jesus is hiervoor noodsaaklik. Oor die 'hoe' van die prediking van hierdie gelykenisse is 'n verdere ondersoek nodig.

\section{LITERATUURVERWYSINGS}

Baars, A., 2004, Om God's verhevenheid en Zijn nabijheid: De Drieeenheid bijCalvijn, Kok, Kampen.

Barnard, A.C., 1981, Die erediens, NG Kerkboekhandel, Pretoria.

Bastian, H-D., 1968, 'Vom Wort zu den Wörtern: Karl Barth und die Aufgaben der Praktischen Theologie', Evangelische Theologie 28, 25-55.

Berger, P., 1967, The sacred canopy: Elements of sociological theory of religion, Doubleday, Garden City.

Berger, P.L. \& Luckmann, T., 1967, The social construction of reality: A treatise in the sociology of knowledge, Anchor Books, New York.

Berkhof, H., 1973, Christelijk geloof, Callenbach, Nijkerk.

Berkouwer, G.C., 1950, De voorzienigheid Gods, Kok, Kampen.

Buitendag, J., 2006, ' "Nuwe wyn in nuwe sakke en die behoud van altwee": 'n Herbedenking van die Hervormde Kerk se identiteit aan die begin van die 21e eeu in Suid-Afrika', HTS Teologiese Studies/Theological Studies 62(2), 343-362.

Buitendag, J., 2006a, 'Coming in from outside: A crucial event in the history of ecumenism of the Nederduitsch Hervormde Church', HTS Teologiese Studies/Theological Studies 62(3), 787-817.

Carter, W., 2006, The Roman Empire and the New Testament: An essential guide, Abingdon, Nashville.

Crossan, J.D., 1998, The birth of Christianity: Discoveirng what happened in the years immediately after the execution of Jesus, Harper, San Francisco.

Dankbaar, W.F., 1982, Calvijn: Zijn weg en werk, Callenbach, Nijkerk.

Dorrien, G., 2001, 'Berger: Theology and sociology', in L. Woodhead (with P. Heelas \& D. Martin) (eds.), Peter Berger and the study of religion, pp. 26-39, Routledge, London.

Durand, J.J.F., 1976, Die lewende God: Wegwysers in die dogmatiek, NG Kerkboekhandel, Pretoria.

Du Toit, H.D.A. (red.), 1963, Vier eeue van troos: Preekbundel oor die Heidelbergse Kategismus, NG Kerk-Uitgewers, KaapstadPretoria.

Heitink, G., 1993, Praktische Theologie: Geschiedenis: Theorie: Handelingsvelden, Kok, Kampen.

Heyns, J.A., 1978, Dogmatiek, NG Kerkboekhandel, Pretoria.

Heyns, L.M. \& Pieterse, H.J.C., 1990, Eerste treë in die praktiese teologie, Gnosis, Pretoria.

Hollenbach, P., 1987, 'Defining rich and poor: Using social sciences', in K.H. Richards (ed.), SBL 1987 Seminar Papers, pp. 50-63, Scholars Press, Atlanta.

Immink, F.G. \& Pleizier, T., 2005, 'Research in homiletics', in A. Grözinger \& H.S.Kang (eds.), Preaching as shaping experience in a world of conflict Studia Homiletica 5, Gospel Works, Singapore.

Immink, F.G. \& Vos, C.J.A., (reds.) 2008, God in 'n kantelende wêreld: Geloof en kerk in veranderende kontekste, Protea Boekhuis, Pretoria.

Jonker, W.D., 1989, Uit vrye guns alleen, NG Kerkboekhandel, Pretoria.

Kwok P-1, Compier, D.H. \& Rieger, J., 2007, Empire and the Christian tradition: New readings of classical theologians, Fortress, Minneapolis.

Malina, B.J., 1987, Wealth and poverty in the New Testament and its world, Interpretation 41, 354-367.

Malina, B.J., 1993, The New Testament world: Insights from cultural anthropology, Westminster, Louisville.

Malina, B.J., 2001, The social gospel of Jesus: The kingdom of God in Mediterranean perspective, Fortress, Minneapolis.

Noordmans, O., 1949, Het koninkrijk der hemelen: Toelichting op de Zondagen VII en XXII van de Heidelbergsen Catechismus, Callenbach, Nijkerk.

Perrin, N., 1976, Jesus and the language of the kingdom: Symbol and metaphor in New Testament interpretation, Fortress, Philadelphia.

Pieterse, H.J.C., 1986, Verwoording en prediking, NG Kerkboekhandel, Pretoria. 
Pieterse, H.J.C., 1993, Praktiese Teologie as kommunikatiewe handelingsteorie, RGN-Uitgewers, Pretoria.

Pieterse, H.J.C., 2008, 'Om oor God te praat in die prediking in die Suid-Afrikaanse konteks van regstellende aksie', in F.G. Immink \& C.J.A. Vos (reds.) 2008, God in 'n kantelende wêreld: Geloof en kerk in veranderende kontekste, Protea Boekhuis, Pretoria.

Polit, D.F. \& Hungler, B.P., 1989, Essentials of nursing research: Methods, appraisal, and utilization, 2nd edn., Lippincot, Philadelphia.

Reinstorf, D. \& Van Aarde, A.G., 1998, 'Jesus' kingdom parables as metaphorical stories: A challenge to a conventional worldview', HTS Teologiese Studies/Theological Studies 54(3\&4), 603-622.

Runia, K., 1985, Het hoge woord in de lage landen, Kok, Kampen.

Sarbin, T.R., 1970, 'The culture of poverty, social identity, and cognitive outcomes', in Poverty, pp. 29-46, Academic Press (Institute for Research on Poverty Monograph Series), New York.

Allen, V.L. (ed.), n.d., Psychological factors in poverty, pp. 2946, Academic Press (Institute for Research on Poverty Monograph Series), New York.

Scott, B.B., 1990, Hear then the parable, Fortress, Minneapolis.

Schottroff, L., 2006, The parables of Jesus, transl. by L.M. Maloney, Fortress, Minneapolis.

Seeman, M. 1959. 'On the meaning of aliniation', ASR 24(6), 783-791.

Van Aarde, A.G., 1988, 'Jesus en die sosiaal-veragtes', HTS Teologiese Studies/Theological Studies 44(4), 892-846.

Van Aarde, A.G., 1994, 'The historical-critical classification of Jesus' parables and the metaphoric narration of the wedding feast in Matthew 22:1-14', in God-with-us: The dominant perspective in Matthew's story, and other essays, pp. 229-247, Gutenberg, Pretoria. (HTS Teologiese Studies/Theological Studies suppl. 5)

Van Aarde, A.G., 1996, 'Armoedekultuur: Die leefwêreld van die Nuwe Testament en die situasie in Suid-Afrika vandag', HTS Teologiese Studies/Theological Studies 52(4), 947-964.

Van Aarde, A.G., 2001, Fatherless in Galilee: Jesus as child of God, Trinity Press International, Harrisburg.

Van Aarde, A.G., 2007a, 'Narrative criticism', in A.B. Du Toit (ed.),
Reading the New Testament: Hermeneutics, exegesis and methods, pp. 295-323, Protea Publishers, Pretoria. (HNT/GNT 3).

Van Aarde, A.G., 2007b, 'Jesus' mission to all of Israel emplotted in Matthew's story', Neotestamentica 41(2), 416-436.

Van Aarde, A.G., 2008a, "Op aarde net soos in die hemel": Matteus se eskatologie as die koninkryk van die hemel wat reeds begin kom het', HTS Teologiese Studies/Theological Studies 64(1), 529-565.

Van Aarde, A.G., 2008b, 'Matthew's intertexts and the presentation of Jesus as healer-messiah', in T.R. Hatina (ed.), Biblical interpretation in early Christian gospels, Volume 2: The Gospel of Matthew, pp. 163-182, T \& T Clark, New York. (Library of New Testament Studies 310)

Van der Ven J.A., 1993, Practical Theology: An empirical approach, Kok Pharos, Kampen.

Van der Ven, J.A., Dreyer, J.S. \& Pieterse, H.J.C., 2000, 'Nature: A neglected theme in practical theology', Religion $\mathcal{E}$ Theology: A Journal of Contemporary Religious Discourse 7(1), 40-55.

Van der Ven, J.A., Dreyer, J.S. \& Pieterse, H.J.C., 2004, Is there a God of human rights? The complex relationship between human rights and religion: $A$ South African case, Brill, Leiden.

Van Eck, E., 2008, 'Eskatologie en koninkryk in die Markusevangelie', HTS Teologiese Studies/Theological Studies 64(1), 567-597.

Van Niftrik, G.C., 1953, Kleine dogmatiek, 4de druk, Callenbach, Nijkerk.

Van't Spijker, W., 1986, "De Fransman ..." Calvijn in 1536, De Groot Goudriaan, Kampen.

Vos, C.J.A., 2008, 'Om die horison te verken: Op soek na 'n eietydse homiletiese hermeneutiek', HTS Teologiese Studies/ Theological Studies 64(1), 111-120.

Wendel, F., 1963, Calvin, Collins, London.

Weren, W.J.C., 1979, De broeders van de Mensenzoon: Mt 25, $31-$ 46 als toegang tot de eschatologie van Mattheüs, Ton Bolland, Amsterdam.

Wright, N.T., 1992, The New Testament and the people of God, SPCK, London.

Zerfass, R.,1974, 'Praktische Theologieals Handlungswissenschaft', in F. Klostermann \& R. Zerfass (Hrsg.), Praktische Theologie heute, pp. 164-177, Chr. Kaiser Verlag/Matthias-GrünewaldVerlag, München. 